\section{FACTORS LINKED TO THE PRACTICE OF PHYSICAL ACTIVITY AMONG THE ELDERLY IN SOUTHERN BRAZIL}

\author{
FATORES ASSOCIADOS Á PRÁTICA DEATIVIDADE FISICA ENTRE IDOSOS NO SUL DO BRASIL
}

FACTORES ASOCIADOS A LA ACTIVIDAD FISICA ENTRE ANCIANOS EN EL SURDE BRASIL

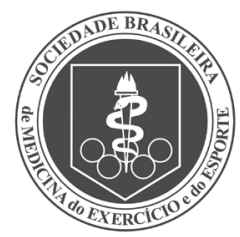

Original Article Artigo Original Artículo Original
Alisson Padilha de Lima' (Physical Education Professional) Ezequiel Vitório Lini² (Physiotherapist)

Marilene Rodrigues Portella ${ }^{2}$ (Nurse)

Marlene Doring ${ }^{2}$

(Nurse)

Fabrício Bruno Cardoso ${ }^{3}$

(Physical Education Professional)

1. Faculdade de Educação Física BOM JESUS/IELUSC, Joinville,

SC, Brazil.

2. Universidade de Passo Fundo (UPF), Postgraduate Program in Human Aging (PPGEH),

Passo Fundo, RS, Brazil.

3. Faculdade de Educação Física - CENSUPEG, Society, Health and Education Research Group, São Fidélis, RJ, Brazil.

\section{Correspondence:}

Alisson Padilha de Lima.

Faculdade de Educação Física BOM JESUS/IELUSC, Rua Mafra,

Distrito de Saguaçu, 80, Joinville,

SC. Brazil. 89221-665.

professor.alissonpadilha@gmail.com

\begin{abstract}
Introduction: The increase in chronic diseases and physical inactivity are major public health problems among elderly populations worldwide. Objective: This article aimed to determine the prevalence and factors associated with the practice of physical activity $(P A)$ among elderly people living in urban environment. Methods: A cross-population-based study was conducted in 2014, with 196 elderly people aged $\geq 60$ years of age living in urban environment in the city of Passo Fundo, in the State of Rio Grande do Sul. Gross and multivariable analyses were conducted using Poisson regression, estimating the ratios of gross and adjusted prevalence and calculating their respective 95\% confidence intervals. Results: The mean age was $71.3( \pm 8.4)$. The gross prevalence for the practice of PA was $56.1 \%$. After adjusted analysis, only the variable independent in activities of daily living (ADLs) remained significant ( $95 \% \mathrm{Cl} 1.05$ to 4.83) ( $p=0.037)$. Conclusions: This research showed an association between the practice of PA and independence in ADLs. Level of Evidence II, Economic and decision analysis - Development of economic model or decision.
\end{abstract}

Keywords: Motor activity; Health status; Ageing population.

\section{RESUMO}

Introdução: O aumento das doenças crônicas e da inatividade física são problemas importantes de saúde pública da população idosa do mundo. Objetivo: Este artigo objetivou determinar a prevalência e os fatores associados à prática de atividade física (AF) entre idosos domiciliados em ambiente urbano. Métodos: Um estudo transversal de base populacional foi realizado em 2014, com 196 idosos com $\geq 60$ anos que vivem em ambiente urbano do município de Passo Fundo, RS. Foram realizadas análises bruta e multivariável mediante regressão de Poisson, estimando-se as razões de prevalência bruta e ajustada, calculando-se os respectivos intervalos de confiança de $95 \%$. Resultados: A média de idade foi de 71,3 ( $\pm 8,4)$. A prevalência bruta de prática de AF foi de 56, 1\%. Depois de ajuste da análise, somente a variável independente das atividades da vida diária (AVD) permaneceu significativa (IC de 95\% 1,05-4,83) $(p=0,037)$. Conclusões: Esta pesquisa mostrou associação entre a prática de AF e independência nas AVD. Nível de Evidência II, Análises econômicas e de decisão-Desenvolvimento de modelo econômico ou de decisão.

Descritores: Atividade motora; Nível de saúde; Envelhecimento da população.

\section{RESUMEN}

Introducción: El aumento de las enfermedades crónicas y la falta de actividad física son los principales problemas de salud pública entre las poblaciones de edad avanzada en todo el mundo. Objetivo: Este artículo tiene como objetivo determinar la prevalencia y los factores asociados con la práctica de actividad física (AF) entre ancianos que viven en entornos urbanos. Métodos: En 2014, se realizó un estudio basado en poblaciones cruzadas, con 196 personas con $\geq 60$ años de edad queviven en entornos urbanos en la ciudad de Passo Fundo en el estado de Rio Grande do Sul. Se realizaron análisis brutos y multivariables mediante la regresión de Poisson, estiman do los ratios de prevalencia bruta y ajustada y calculando sus respectivos intervalos de confianza del 95\%. Resultados: La edad media fue de 71,3 ( $\pm 8,4$ ). La prevalencia bruta de la práctica de AF fue $56,1 \%$. Después del ajuste del análisis, sólo la variable independiente en las actividades de la vida diaria (AVD) se mantuvo significativa (IC del 95\%: 1,05 a 4,83) ( $p=0,037)$. Conclusiones: Este estudio mostró asociación entre la AFy la independencia en las AVD. Nivel de evidencia ll, Análisis económico y de decisión - Desarrollo de modelo económico o de decisión.

Descriptores: Actividad motora; Estado de salud; Envejecimiento de la Población.

\section{INTRODUCTION}

The increase of chronic diseases and physical inactivity have been one of the greatest public health problems and risk factors to functional independence in the elderly. ${ }^{1}$ The technological progress and industrialization have been contributed to a lifestyle prone to downtime, negatively impacting the conditions of physical and cognitive health during the aging process. ${ }^{2}$
Encouraging the promotion of physical activity (PA) which includes: increase in intensity and volume in the fields of transport, household chores, work and leisure time, seeking to achieve 150 minutes per week in moderate activities it is pivotal to the elderly health. ${ }^{3}$

Among the PA different benefits to elderly, it can be highlighted the improvement cardiorespiratory fitness and muscular, promotes 
bone and functional health, reduce falls, of non communicable chronic diseases, depression and cognitive disorders, cardiovascular disease and type II diabetes. ${ }^{4}$ And reduce by up to $31 \%$ the mortality index when compared to less active individuals, with greater benefits in elderly aged 60 years or more..$^{5}$

Despite the strong campaign in favor of PA benefits, praised in different media vehicles, it is high the number of sedentary young and elderly people. Indeed, there are many differences when it comes to different countries and contexts. In 2011 a study carried out with 76 countries proved that physical inactivity rate varies from $2,6 \%$ to $62,3 \%$, one in five adults considered physically inactive, especially women and elderly. The richest countries and, mainly urban show higher percentage of physical inactivity. ${ }^{6}$

The elderly need to be stimulated, even with no conditions to achieve the PA quantity recommended due to health conditions, they must be encouraged to be as active as their conditions allow them to. ${ }^{4}$

Apart from the context experienced, the PA is crucial to the prevention of typical diseases such as muscular atrophy, being a limiting factor for the functional independence of the elderly.

The American College of Sports Medicine and the American Association of Health recommend that the PA intensity and duration must be low for elderly in the beginning, due the fact they are highly unconditioned, functinally limited, or suffer from chronic diseases that could affect the ability of performing physical tasks. The activities progression must be individual and personalized, as well as muscle strengthening and balance activities may be necessary before starting aerobic training on very frail elderly. ${ }^{8}$

On the above, the article aimed verifying the prevalece and factors linked to the PA practice in domiciled elderly in an urban context.

\section{METHODS}

Cross- population-based study with 196 elderly aged $\geq 60$ years of age in urban homes in the city of Passo Fundo/RS, 2014.

The city of Passo Fundo is located in Rio Grande plateau 690 meters above sea level on average, north of Rio Grande do Sul state, having a territorial unit of $783.42 \mathrm{Km}^{2}$. The estimated population by the census of July 2015 is 196,749 inhabitants, which sets up among the ten largest cities in the state. ${ }^{9,10}$

The sample was selected according to the urban territorial division marked the Coordination of Social Protection county Basic. This institution provides the performance of each quadrant of Social Assistance Reference Center (SARC), divided into four major sectors: Sector I Northeast Region; Sector II - Northwest Region; Sector III - Southeast Region; Sector IV - sectors has drawn up a Family Health Strategy (FHS), in which it was searched the records (name and address) of the elderly. In sector I, due to the absence of FHS, it was decided to interview the elderly enrolled in Basic Health Unit (BHU) with coverage similar to FHSs.

It was considered losses eight elegible elderly individuals: three for refusal; three not found at home after three attempts, in alternated days and time; two deaths, which represented 4,4\%. Elderly living in long term care facilities and hospitalized were excluded.

Data was collected in the residences, from a structured questionnaire prepared by the researchers, and applied to the elderly considering sociodemographic variables (gender, age, education - years of study- , dichotomous marital status - with and without a partner (a), health-related (Parkinson's disease, diabetes mellitus, hypertension, kidney disease, respiratory, arthritis / arthrosis, cancer, dependence for basic activities of daily living - ADL and self-reported health status).

All the investigation about the diseases was carried out according to the medical records of each elderly. In the questioning about PA, physical activity was considered as a self-reported for not using a specific tool to assess the PA levels of this population, in other words, the elderly were asked if they practiced some PA on a daily basis respecting the three areas of classification (household chores, work activities and leisure activities). It was explained its meaning and exemplified the PA to each one of them, so that they could understand and classify if they practiced PA (yes or no).

Katz index, Katz et al. ${ }^{11}$ was used to evaluate the performance to ADLs, which evaluate the functional capacity to perform some basic daily activities such as bathing, dressing, going to the toilet, bed transfers to chair and vice - versa, control over the sphincters and feeding without assistance. Elderly with classification A were considered independent, in other words, independent to all the activities, and dependents the ones classified B, C, D, E, F, G and Other, in other words, dependent to, at least, one activity.

An analysis decriptive and bivariate of the data was carried out. Gross analysis and multivariable Poisson regression were carried out to test the link between the outcome and independent variables, estimating the ratios of gross and adjusted prevalence and calculated the respective 95\% confidence intervals. They entered the multiple model all variables with $p \leq 0,20$.

The research project was approved by the Research Ethics Committee of the University of Passo Fundo, in the opinion number 504100/2014 and the elderly or their guardians signed informed consent and informed prior to the interview.

\section{RESULTS}

The average age was $71,3( \pm 8,4)$. The prevalence of the PA practice was $56,1 \%$. Among the elderly dependent to ADLs, 73,7\% did not practice PA. The analysis showed that being independent to ADLs increases meaningly the prevalence ratio to the PA practice when compared to the ones who are dependent.

In the link with the PA and sociodemographic variables (Table 1) no variable statistically significant.

In the gross analysis, only the variable being independent to ADLs was linked significantly to the PA practice. (Table 2)

After adjusted analysis, only the variable being dependent to the ADLs remained significative (CI 95\% 1.05-4.83) $(p=0.037)$. Three variables were in the model: Hypertension ( $p=0.107)$, Cancer $(p=0.071)$ e ADLs $(p=0.037)$.

Table 1. Gross analysis of elderly regarding the sociodemographic variables. Passo Fundo, RS, Brasil, 2014 ( $n=196)$.

\begin{tabular}{|c|c|c|c|c|}
\hline \multirow{3}{*}{ Variables } & \multicolumn{2}{|c|}{ Physical activity } & \multirow{3}{*}{$\begin{array}{l}\text { Gross PR } \\
\text { (Cl 95\%) }\end{array}$} & \multirow{3}{*}{$\mathbf{p}^{*}$} \\
\hline & Yes & No & & \\
\hline & n (\%) & n (\%) & & \\
\hline \multicolumn{5}{|l|}{ Gender } \\
\hline Female & $65(55,1)$ & $53(44,9)$ & 1,00 & \\
\hline Male & $45(57,7)$ & $33(42,3)$ & $1,05(0,81-1,35)$ & 0,717 \\
\hline \multicolumn{5}{|l|}{ Age group } \\
\hline 80 and more & $2(40,0)$ & $3(60,0)$ & 1,00 & \\
\hline $70-79$ & $6(21,4)$ & $22(78,6)$ & $0,54(0,15-1,94)$ & 0,342 \\
\hline $60-69$ & $102(62,6)$ & $61(37,4)$ & $1,56(0,53-4,61)$ & 0,417 \\
\hline \multicolumn{5}{|l|}{ Education } \\
\hline Illiterate & $10(47,6)$ & $11(52,4)$ & 1,00 & \\
\hline From 1 a 4 years & $65(58,6)$ & $46(41,4)$ & $1,26(0,72-2,20)$ & 0,426 \\
\hline From 5 a 8 years & $26(59,1)$ & $18(40,9)$ & $1,24(0,73-2,11)$ & 0,417 \\
\hline 9 of over & $8(47,1)$ & $9(52,9)$ & $1,01(0,51-1,99)$ & 0,973 \\
\hline \multicolumn{5}{|l|}{ Marital status } \\
\hline Without a partner & $50(51,5)$ & $47(48,5)$ & 1,00 & \\
\hline With a partner & $60(60,6)$ & $39(39,4)$ & $1,18(0,92-1,51)$ & 0,204 \\
\hline
\end{tabular}


Table 2. Gross analysis of elderly regarding health variables. Passo Fundo, RS, Brasil, $2014(n=196)$.

\begin{tabular}{|c|c|c|c|c|}
\hline \multirow{3}{*}{ Variables } & \multicolumn{2}{|c|}{ Physical activity } & \multirow{3}{*}{$\begin{array}{l}\text { Gross PR } \\
\text { (Cl 95\%) }\end{array}$} & \multirow{3}{*}{$\mathrm{p}^{*}$} \\
\hline & Yes & No & & \\
\hline & n (\%) & $\mathrm{n}(\%)$ & & \\
\hline \multicolumn{5}{|c|}{ Parkinson's disease } \\
\hline Yes & $1(25,0)$ & $3(75,0)$ & 1,00 & \\
\hline No & $109(56,8)$ & $83(43,2)$ & $2,27(0,41-12,45)$ & 0,345 \\
\hline \multicolumn{5}{|l|}{ Mellitus diabetes } \\
\hline Yes & $22(53,7)$ & $19(46,3)$ & 1,00 & \\
\hline No & $88(56,8)$ & $67(43,2)$ & $1,06(0,77-1,45)$ & 0,726 \\
\hline \multicolumn{5}{|c|}{ Arterial hypertension } \\
\hline Yes & $72(52,6)$ & $65(47,4)$ & 1,00 & \\
\hline No & $38(64,4)$ & $21(35,6)$ & $1,23(0,96-1,57)$ & 0,107 \\
\hline \multicolumn{5}{|l|}{ Kidney disease } \\
\hline Yes & $6(66,7)$ & $3(33,3)$ & 1,00 & \\
\hline No & $104(55,6)$ & $83(44,4)$ & $0,83(0,52-1,35)$ & 0,459 \\
\hline \multicolumn{5}{|c|}{ Respiratory diseases } \\
\hline Yes & $10(55,6)$ & $8(44,4)$ & 1,00 & \\
\hline No & $100(56,2)$ & $78(43,8)$ & $1,01(0,66-1,56)$ & 0,960 \\
\hline \multicolumn{5}{|c|}{ Arthritis/Osteoarthritis } \\
\hline Yes & $21(63,6)$ & $12(36,4)$ & 1,00 & \\
\hline No & $89(54,6)$ & $74(45,4)$ & $0,86(0,64-1,15)$ & 0,306 \\
\hline \multicolumn{5}{|l|}{ Cancer } \\
\hline Yes & $7(33,3)$ & $14(66,7)$ & 1,00 & \\
\hline No & $103(58,9)$ & $72(41,1)$ & $1,77(0,95-3,28)$ & 0,071 \\
\hline \multicolumn{5}{|l|}{$A D L s^{* *}$} \\
\hline Dependent & $5(26,3)$ & $14(73,7)$ & 1,00 & \\
\hline Independent & $105(59,3)$ & $72(40,7)$ & $2,25(1,05-4,83)$ & 0,037 \\
\hline \multicolumn{5}{|l|}{ Health state } \\
\hline Regular/bad & $47(51,6)$ & $44(48,4)$ & 1,00 & \\
\hline Excellent/good & $63(60,0)$ & $42(40,0)$ & $1,16(0,90-1,50)$ & 0,245 \\
\hline
\end{tabular}

* $\mathrm{P}$ - value obtained by the Wald test of Poisson regression. ** Activities of Daily Living.

All of them lost statistic significance when put in the model. When the variable model ADLs was withdrawn the other two lost statistic significance. In other two situations in which the variable ADLs remained in the model (followed by the variable cancer and hypertension), only this one remained under 0.05 . Therefore, the prevalence of PA practice was 2.25 times higher among the elderly without dependence to daily life activities when compared to the ones who are dependent to these tasks.

\section{DISCUSSION}

After adjusted analysis to the link between the PA practice, only the variable being independent to ADLs showed significance.

These findings point that this study presented some limitations due to the design not estimate the incidente of diseases linked to the PA practice, the distinct chronology between the exposition and the risk factor appearance which may interfere the PA practice. But also identifies only the positive aspects such as: a fast method, practical and low cost to test the effect and interaction of a great number of factors which relate to the studied event, in this case the PA.

The PA prevalence in elderly who live in urban homes detected in this study $(56,1 \%)$ was higher to the one found in a broad study carried out in Portugal, with 4696 participants aged over 10 years, the researchers stratified the ages among the data verified, it was found the prevalence of elderly considered active ( $\geq 150$ minutes/week of moderate or vigorous intensity) of $35 \% .^{12}$

In Ireland, Murtagh et al. ${ }^{13}$ used IPAQ (International Physical Activity Questionnaire) instrument and determined that 28,9\% of the elderly could be considered active. The prevalence in others studies showed them under the one found in our study possibly explained by the use of specific instruments to determine the activity intensity and time that authors used, while our gathering was based on the elderly report before the possible physical activities performed by them, which may have beget a subjectivity situation likely to overestimate the PA practice.

It is expected that elderly in younger age groups practice more PA. In an Irish study with more than 4.000 elderly over 60 years old it was observed that the percentage os elderly considered active decreases as they age. The National Sports Diagnoses mentions that the greater the age group, broader is the physical inactivity in the Brazilian popultion. Finding $64,4 \%$ foi Brazilian aged 54 to 74 are inactive. ${ }^{14}$

The main barriers reported by elderly to practice PA are poor health and lack of company and interest. The elderly aged 80 clarim that poor health is the main barrier to practice PA. ${ }^{15}$

However, it is never too late to become physically active, and feel the associated benefits. "Being too old", "very fragile or impaired" are not reasons themselves to an elderly not practice PA. Actually, older people fall ill or deficient more frequently if they do not practice PA. The majority of the physical activities can be adapted to older people with multiple health problems. The PA also can improve the health of elderly with chronic conditions such as stroke or arthritis, although the activity may need to be modified during periods of acute symptoms of the disease. ${ }^{16}$

The PA practice promotes countless benefits, especially in cardiovascular system. In a study with review and meta-analysis, Li and Siegrist ${ }^{17}$ concluded that PA practice reduces from 10\% up to 30\% the risk of cardiovascular disease in men and women. It is important to highlight that this review did not take into consideration the age of the participants.

The Brazilian Hypertension Society (BHS) points that over $50 \%$ of the elderly population suffers from arterial hypertension. The BHS recommend the PA practice ( 5 times per week) as prevention and reduction of hypertension measure. ${ }^{18}$

The National Institute on Aging ${ }^{19}$ suggest some changes in lifestyle to tackle and prevent arterial hypertension. It suggests, among other measures, the daily PA practice with mild to moderate with a gradual increase until reaching 30 minutes/day. Therefore, secured evidence show that the individual who practice PA presents lower risk to develop hypertension and also, the PA acts as a regulator of blood pressure in hypertensive patients.

Being independent to the ADLs can be a facilitator to PA practice, as presented in this research, and confirmed in the Keevil et al. ${ }^{1}$ study that identified through a cohort study in elderly aged 75 to 90 years old. In old age the increase of the time spent with the PA practice of moderate intensity can help to keep a greater physical mobility to perform ADLs in free spaces.

The physical inactivity contributes to the appearance of dependence to the ADLs. According to Dunlop et al. ${ }^{20}$ investigasting 2.286 individuals over 60 years old, analyzed the hours spent per day in sedentary behavior. Different collections carried out for a period of three years showed in their analysis that the chances of developing dependence to ADLs were $46 \%$ higher (OR $=1.46$ - C195\% 1.07 to 1.98 ) for each hour/day (above the average of $8.9 \mathrm{~h} /$ day) spent on sedentary behavior.

It is highlighted among the factors linked to disability in elderly the presente of multiple diseases, chronic pain and physical inactivity. ${ }^{21}$ The World Health Organization ${ }^{4}$ highlights the PA practice for elderly reflected in lower mortality rates, coronary heart disease, hypertension, type II diabetes, better cardiovascular and muscular fitness, lower risk 
of falling, better cognitive function reflecting, therefore, reduced risk of functional limitations.

The PA practice has been worked as an importante ally to prevent disability. In a North American clinical trial with 1.635 elderly with physical limitations, it was conducted moderate PA in group one and in group two held education workshops on health and stretches. Over 2.6 years the incidence of worsening of disability in group one was significantly lower $(p=0.03)$. There was less persistent limitation in group one $(p=0.006)$. Thus, the authors considered the effective practice of PA in preventing major disability with decreased risk of developing or persisting with disability. ${ }^{22}$

\section{CONCLUSIONS}

This research showed association to the PA practice being independent to daily activities. These results must be understood with caution, since they do not show cause and effect of these associations.

It is recommended that other studies be carried out with larger populations in different contexts, proving the effectiveness of physical activity practice and its health prevention factors and improvement of the quality of life.

All authors declare no potential conflict of interest related to this article

AUTHORS' CONTRIBUTIONS: Each author made significant individual contributions to this manuscript. APL (0000-0002-6062-446X)* and EVL (0000-0003-4696-7068)* were the main contributors in the writing of the manuscript and the statistical analysis and were the idealizers of the research; MRP (0000-0002-8455-7126)* MD (0000-0001-8551-8551)* and FBC (0000-0001-6185-4622)* participated in the critical review of content and final approval of the manuscript in all respects. *ORCID (Open Researcher and Contributor ID).

\section{REFERENCES}

1. Keevil VL, Cooper AJ, Wijndaele K, Luben R, Wareham NJ, Brage S. et al. Objective Sedentary Time, Moderate-to-Vigorous Physical Activity, and Physical Capability in a British Cohort. Med Sci Sports Exerc. 2016;48(3):421-9.

2. Wu F, Guo Y, Chatterji S, Zheng Y, Naidoo N, Jiang Y. et al. Common risk factors for chronic noncommunicable diseases among older adults in China, Ghana, Mexico, India, Russia and South Africa: the study on global ageing and adult health (SAGE) wave 1. BMC Public Health. 2015;15(88):1-13.

3. Vagetti GC, Barbosa Filho VC, Moreira NB, Oliveira V, Mazzardo O, Campos W. The Association Between Physical Activity and Quality of Life Domains Among Older Women. J Aging Phys Act. 2015;23(4): 524-33.

4. World Health Organization. Physical Activity and Older adults. Geneva: WHO Press. 2010. [acesso em 20 mar. 2016]. Disponivel em: http://www.who.int/dietphysicalactivity/factsheet_olderadults/en/

5. Arem H, Moore SC, Patel A, Hartge P, Berrington de Gonzalez A, Visvanathan K. et al. Leisure time physical activity and mortality: a detailed pooled analysis of the dose-response relationship. JAMA Intern Med. 2015;175(6):959-67.

6. Dumith SC, Hallal PC, Reis RS, Kohl HR. Worldwide prevalence of physical inactivity and its association with human development index in 76 countries. Prev Med. 2011;53(1-2):24-8.

7. Ikezoe T, Nakamura M, Shima H, Asakawa Y, Ichihashi N. Association between walking ability and trunk and lower-limb muscle atrophy in institutionalized elderly women: a longitudinal pilot study. J Physiol Anthropol. 2015;28:34:31.

8. American College of Sports Medicine. Quantity and Quality of Exercise for Developing and Maintaining Cardiorespiratory, Musculoskeletal, and Neuromotor Fitness in Apparently Healthy Adults: Guidance for Prescribing Exercise. Med Sci Sports Exerc. 2011;43(7):1334-59.

9. Prefeitura Municipal de Passo Fundo. Plano Municipal de Saúde: 2014-2017. Secretária de Saúde. Passo Fundo/RS, 2014.

10. Instituto Brasileiro de Geografia e Estatística. Estimativas da população residente no Brasil e unidades da federação com data de referência de 1 de julho de 2015. Rio de Janeiro. 2015. [acesso em 2015 dez 15]. Disponível em: ftp://ftp.ibge.gov.br/Estimativas_de_Populacao/Estimativas_2015/ estimativa_2015_TCU.pdf.
11. Katz S, Ford AB, Moskowitz RW, Jackson BA, Jaffe MW. Studies of illness in the aged. The index of ADL: a standardized measure of biological and psychosocial function. JAMA. 1963;185:914-19.

12. Baptista F, Santos DA, Silva AM, Mota J, Santos R, Vale S. et al. Prevalence of the portuguese population attaining sufficient physical activity. Med Sci Sports Exerc. 2012;44(3):466-73.

13. Murtagh EM, Murphy MH, Murphy NM, Woods C, Nevill AM, Lane A. Prevalence and Correlates of Physical Inactivity in Community-Dwelling Older Adults in Ireland. Plos One. 2015;10(2):1-11.

14. Brasil, Ministério do esporte. Diesporte: Diagnóstico Nacional do Esporte. Caderno 1, Brasília-DF Ministério do esporte, 2015.

15. Moschny A, Platen P, Klaassen-Mielke R, Trampisch U, Hinrichs T.Barriers to physical activity in older adults in Germany: a cross-sectional study. Int J Behav Nutr Phys Act. 2011;8:121.

16. Department of Health Australian. Government. Recommendations on physical activity for health for older Australians. 2013. [acesso em 2016 mar 20]. Disponível em: http://www.health.gov.au/ internet/main/publishing.nsf/content/phd-physical- ec-older guidelines.

17. Li J. Siegrist J. Physical Activity and Risk of Cardiovascular Disease - A Meta-Analysis of Prospective Cohort Studies. Int J Environ Res Public Health. 2012;9(2): 391-407.

18. Sociedade Brasileira de Hipertensão. Como tratar a hipertensão. [acesso em 2016 mar 20]. Disponível em: http://www.sbh.org.br/geral/como_tratar.asp

19. National Institute on Aging. High Blood Pressure. [acesso em 2016 mar 20]. https://www.nia.nih gov/health/publication/high-blood-pressure\#control

20. Dunlop DD, Song J, Arnston EK, Semanik PA, Lee J, Chang RW. Sedentary time in U.S. older adults associated with disability in activities of daily living independent of physical activity. J Phys Act Health. 2015;12(1): 93-101.

21. Trize DM, Conti MHS, Gatti MAN, Quintino NM, Simeão SFAP, Vitta A. Fatores associados à capacidade funcional de idosos cadastrados na Estratégia Saúde da Família. Fisioter Pesqui. 2014;21(4):378-83.

22. Pahor M, Guralnik JM, Ambrosius WT, Blair S, Bonds DE, Church TS. Effect of Structured physical activity on prevention of major mobility disability in older adults: the LIFE study randomized clinical trial. JAMA. 2014;311(23): 2387-2396. 